\title{
En moderne skjald
}

En analyse af William Heinesens Laterna Magica

»Promenade og promenade - ja, det kan vi jo godt kalde det. Det lyder så rart uforpligtende, som havde vi masser af tid foran os og kunne hengive os til hyggelig slentren og passiar.

Men der er jo det, at båden venter. Færgebåden, ja. Den ligger og venter ude ved Gråskallebryggen. Der har den allerede ligget og ventet længe. Og selv om den gamle færgemand er en sindig og tålmodig mand.

Og vi må helst starte før det bliver mørkt.«

Sådan indleder William Heinesen sin novellesamling fra 1985 Laterna Magica. Og hermed er en eksplicit fortælleramme lagt: Læseren suges ind $\mathrm{i}$ fortællerens verden $\mathrm{i}$ kraft af hans forlokkende »vi« og får lov at spille den udtalte rolle som tilhører. Det, læseren skal lokkes med på, er en vandring gennem Torshavn, en "promenade $\mathrm{i}$ aftendæmringen.« I betragtning af, at vandringens endelige mål er »Gråskallebryggen «, hvor en færøsk Charon venter med sin båd, er det intet under, at fortælleren bestandigt forhaler fremaddriften med sine historier - som Sheherazade forhaler sin halshugning, som Decamerons fortællere holder pesten fra døren.

9 små noveller bliver det til - gennem 9 historier skal fortælleren gå svanger med døden. Han starter blidt: De tre første noveller (»De stumme gaster «, »Mester Jakob og Jomfru Urd «, »Stive Stine «) er mere interesserede $\mathrm{i}$ stemning end handling; vi bliver nænsomt præparerede lyrisk, inden vi kastes ud i episk virvar. Derpå følger to voldsomme eper: »Lykkestenen« og "Syndefaldet «, hvorefter vi - hårdt tiltrængt ovenpå de dramatiske begivenheder - făr lov at puste ud med den lille legendeagtige beretning »Miraklet«. Så kastes vi igen ud i dramatisk, ja tragisk, handling med »Balladen om Bøledrengen«, og derpå følger endnu et lyrisk pusterum, nemlig samlingens titelstykke »Laterna Magica «. Endelig sluttes der af med epet »Sprøjteprøven« - eller der sluttes foreløbigt af: Typisk for den forhalende fortællestrategi bærer »Sprøjteprøven« undertitlen »en provisorisk epilog $\ll$. 
Trukket op i store linier kommer den fortællende vandring gennem Torshavn altså til at forme sig som fire store eper, indledt af lyrisk opvarmning og afbrudt af lyriske åndehuller. "Laterna Magica« ... Det kan umiddelbart undre, at en samling fortællinger fra Færøerne med norrøne undertoner af saga og kvad har fået så fremmed og teknisk et navn. Ligger Heinesen $\mathrm{i}$ den grad under for den moderne visuelle medieverden, at han vælger at annoncere sine historier som en række snapshots fra Torshavn? Måske. Kigger man på bogens omslag, tegnet af Heinesen selv, kommer man imidlertid i tanke om, at der findes andre magiske lanterner end den vidundermaskine, der indledte filmalderen. Her ser man nemlig en sort kat profilere sig mod en stor rød måne. Månen får lov at optræde $\mathrm{i}$ novellesamlingen som en evighedens repræsentant, og, som vi skal se, bliver den til en vis grad en identifikationsfigur for fortælleren.

Afslørende er det også, at samlingens titelstykke handler om, hvorledes den med spænding ventede lanterne aldrig kommer til at vise sine billeder i Torshavn: "Madam Abrahamsen kunne ikke få lyset til at fungere ordentligt, og en klejnsmed som der sendtes bud efter var ikke hjemme. Så blev forestillingen udsat til en anden gang, men af nu glemte årsager aldrig ført ud i virkeligheden « (p.116). At lanternen aldrig kommer til at virke, er imidlertid fuldstændig underordnet på novellens tematiske plan: Den forventningens glæde, den har antændt i de små torshavnske drenge, er en kraft i sig selv, som ikke slukkes af den grund. På et skrifttematisk plan er det derimod ikke underordnet, at vidundermaskinen udebliver det er simpelt hen forudsætningen for, at novellen overhovedet skrives. Den udeblevne maskine bliver anledning til en smuk historie; fortælleren kan nok få lyset til at fungere. Har man brug for en klejnsmed, kan man også trygt gå til ham: Det er ham, der smeder »småstadens enkle nøgler «, som »passer i næsten alle menneskelige dørlåse« (»De stumme gæster«, p.12). Moderne vidundermaskiner har intet at sige mod fortællingens magiske lys.

Og dog - som lysmester og klejnsmed vedgår fortælleren en vis teknisk indsigt, som også kommer til at præge hans fortælling. Magisk måneskin eller magisk maskine - Heinesens novellesamling er begge dele, den bevæger sig $i$ et samspil mellem tradition og modernitet, mellem myte og tydeligt fabrikeret skrift.

Disse indledende betragtninger har udlagt to spor til analyse af novellesamlingen, to spor, der skærer igennem hvert sit teoretiske landskab.

Fortællerens traditionalisme, den eksplicit fremskrevne mundtlige 
fortælling, indbyder til en undersøgelse af fortælleren $i$ den forstand, Walter Benjamin definerer ham i sit essay »Der Erzähler « - den fortæeller, hvis historier bliver til visdom, når de »væves ind $\mathrm{i}$ det levede liv« (Benjamin IV). En mere antropologisk tilgang til denne fortæller finder vi i Walter J. Ong's Orality and Literacy. Den fortællerens død, der for Benjamin indtraf $i$ 1. verdenskrigs skyttegrave, er i Ongs perspektiv stort set allerede indtruffet med skriftens opfindelse.

Den forhalende fortællestrategi, færgemanden ved Gråskallebryggen og månefortælleren, der hæver sig over timeligheden, påkalder Peter Brooks og hans begreber om narrativ tid og narrativt begær i Reading for the Plot, der i øvrigt tæller Benjamins essay blandt sine inspirationskilder.

Disse to teoretiske spor vil jeg i løbet af det følgende søge at få til at mødes, idet det er min tro, at en analyse, der suger næring af Brooks' dynamiske tekstsyn (men i øvrigt, som Brooks, vedkender sig sit strukturalistiske bagland), kan hjælpe os til at genopdage fortællingen $\mathrm{i}$ benjaminsk forstand, igen at betragte litteraturen som noget, der kan væves ind $i \gg d e t$ levede liv« på trods af moderne sammenbrud og postmoderne nedbrydninger.

\section{Fortoelleren}

En skriftlig fremstilling af en mundtlig fortællesituation er selvfølgelig $i$ sig selv en tvetydig størrelse - vi står overfor en lumsk dobbeltfortæller, der både er skjald og psykolog.

Som skjald har han brug for en tilhører, der er tæat på hans eget univers. Denne tathed eller indforståethed etableres på raffineret vis i en lille indskudt sæetning som: 》- det var jo ham, der som alle ved gerne ville række Stive Stine (...) en hjælpende hånd...« (»Lykkestenen«, p. 29). Her kan læseren tilfreds føle sig som en del af »alle« de indforståede fordi fortælleren i den foregående novelle har forsynet ham/hende med den viden, han nu henviser til! Samme mekanisme træder i virkeligheden $i$ kraft hver gang en person går igen (her er det Konrad P. Olsen, senere bliver det Sorte-Kristen og Stærke-Johan, som vi møder både i »Lykkestenen« og »Syndefaldet «). Dette er i øvrigt et fænomen, der går gennem hele forfatterskabet, således at de samme personer optræder i flere forskellige af Heinesens værker. For at genkende må man kende, og læseren får derved en følelse af at kende det fortalte univers og dets personer, skønt han blot har hørt dem næunt, hvilket skaber en hyggelig 
stemning af indforstået fortrolighed. ${ }^{1}$

Tilhøreren hives også på mere håndgribelig vis ind $\mathrm{i}$ fortællerens univers: „Vær så god at træde ind...«, lyder opfordringen ligefrem et sted (»Syndefaldet «, p.52), og lignende direkte henvendelser minder os jæunligt om tilhørerens tilstedeværelse. Men i en mundtlig fortællesituation er tilhøreren ikke bare passiv modtager - han reagerer på det fortalte, og hans reaktioner tages op af fortælleren. ${ }^{2}$ Sådanne tilhørerreaktioner oplever vi flere gange på vandringen gennem Torshavn: Som spørgsmål af uddybende eller kommenterende art ( $~ O \mathrm{Om}$ hvad taler Mester Jakob og Jomfru Urd? «, p.19, »Burde hun ikke have ladet ham sejle sin egen $\mathbf{\varnothing}$ ? «, p.24), som kropslige signaler, der registreres af fortælleren (»Du smiler lidt pikeret«, p.41) eller som forventede reaktioner (»Hvad der skete den dag ved jeg godt, at du vil stille dig skeptisk til...«, p.77). Den eksplicitte tilhører sikrer på denne måde fortælleren det modspil, der kan drive hans fortælling frem. Han virker ikke kun befordrende på skriveprocessen, men også på læseprocessen: Fortælleren bruger ham til at imødekomme vanskeligheder som ugidelighed (»Det er muligt, du ikke forstår eller gider...«, p.38) og eksplicit påkalde sig læserens forestillingsevne (»Jeg tror, du kan tænke dig til...«, p.57). Kort sagt sikrer den tilstedeværende tilhører det dialogiske element, uden hvilket en mundtlig fortællesituation er utænkelig.

Men faktisk må den eksplicitte tilhører også finde sig i modernistisk misbrug, idet han giver fortælleren lejlighed til at tematisere sin egen fremstillingsmåde, forsvare sin holdning til det fortalte. Med dette metaelement bevæger vi os ud over den »mundtlige« bevidstheds grænser: Den selvobjektivering, det fordrer, kræver den evne til at skelne mellem den erkendende og det erkendte, som jvf. Ong først eksisterer i den »skrivende« bevidsthed. Psykologens stemme begynder at overdøve skjaldens, den skrivende fortæller kigger frem bag sin maske-mund.

Den mundtlige maskering udgøres ikke blot af dialogens eksplicitering, også grammatisk, tematisk og genremæssigt slår den igennem. Grammatisk i en parataktisk syntaks, der svarer til den additive fremfor subordinative udtryksmåde, Ong fremhæver som typisk »oral« (Ong, p.37). Tematisk $\mathrm{i}$ de hyppigt forekommende agoner (=tvekampe), henvisningen til skæbnen ${ }^{3}$ samt visse $\gg$ heavy figures « (Ong's betegnelse), dvs. personer med tendens til at antage typekarakter, såsom den varme Varme-Fanny, den moderlige Bøle-Anna, den gode Stærke-Johan etc. I $\emptyset$ vrigt er også brugen af tilnavne i god overensstemmelse med mundtlig kultur, som vi kender den helt tilbage til de homeriske epiteter, eller »Leif den Lykkelige og "Erik den Røde«s tid for nu at holde os på mere 
relevante himmelstrøg. Genremæssigt i valget af novelle fremfor roman: Som fremhævet $\mathrm{i}$ denne artikels indledning unddrager rækken af fortællinger sig den éne store slutning, dvs. det »closure of plot« (Ong, p.147) eller den »finis« (Benjamin XIV), som man først kan få fornemmelse for, da skriften gør det muligt at nedfælde beretninger som fysisk afgrænsede enheder. På et mindre abstrakt genreniveau er de jævnligt forekommende formler, remser, omkvæd tydelige påkaldelser af mundtlighed.

Men masken revner konstant og må naturligvis gøre det, da det rent faktisk er et stykke skrift, vi sidder med. Paratakse skifter med hypotakse. De »tunge figurer « er måske ikke så tunge endda; fortælleren afslører en bevidsthed om, hvordan han gør dem tunge ved at bade dem i mytens lys (for en »traditionel verdslig observans er Bøle-Anna $\mathrm{i} »$ Balladen om Bøledrengen « almindelig, som »mytisk, fiktiv figur « er hun en Mater Dolorosa, $\mathrm{p} .87^{4}$ ) og bevæger sig hermed endnu en gang ud på et modernistisk meta-niveau. Det skal ikke nægtes, at en del personer forbliver typer: Karikaturer som den skinhellige Konrad ("Lykkestenen «) og fremskridtsmanden Blüthner (»Sprøjteprøven«) og symbolske abstraktioner som Varme-Fanny, men disse figurer danner baggrund for mere komplicerede naturer: Mod Konrad profileres Griseldis, mod Blüthner Umbertsen, og mod Fanny Johan og Fingal. Hvad angår henvisningen til skæbnen sørger den moderne, skrivende fortæller for at indlægge så mange brikker til psykologiske forklaringsmønstre, at det står læseren frit for, om han vil samle disse eller stilles tilfreds med den mundtlige fortællers pegen på ydre tilskikkelser. Det er »en drilagtig skæbnens tilskikkelse«, der får Johan til at kaste sig over den dampende Fanny som en brunstig tyr, hæudes det ("Lykkestenen«), og så kan vi jo efter behag tro på den eller foretage koblingen tilbage til Johans kone Nikoline og hendes malkefattige bryster.

På samme måde smuldrer den genremæssige mundtlighed: Fortælleren er så bevidst om sit genrevalg, at han selv kan annoncere sin fortælling som »saga ( (Lykkestenen«) eller »kvad “ ("Balladen om Bøledrengen«), og kigger man nærmere på remserne og formlerne, opdager man, at også de har meta-karakter. »Øre høre og øje løje « hedder det $\mathrm{i}$ den lille digression i »Mester Jakob og Jomfru Urd«, og hermed hentydes til de åbne sanser, fortælleren må være udstyret med for at videregive de nøgler til menneskesindet, han mener at finde $\mathrm{i}$ småstaden. "Jeg er dig og du er mig « rapper han sammesteds med ænderne og legetimerer hermed sin fortællings almengyldighed, dens relevans for selv den fjerne læser. »Vel op før dag, vi komme vel over den hede« er omkvædet til sangen om 
Bøledrengen, der kommer i fængsel for fadermordsfors $\emptyset \mathrm{g}$ og kaster sig i havet, da han får at vide, at hans elskede er hans egen kødelige søster. Igen et omkvæd om de åbne sanser, om den årvågenhed, Bøledrengen skulle have lagt for dagen for at undgå sin incestuøse skæbne. Der er bare det ved det, at Bøledrengens skæbne er tragisk i klassisk forstand: årvågenhed alene ville ikke have kunnet udbedre hans fatale uvidenhed. Faktisk kan denne kun udbedres retrospektivt, altså med fortællerens tilbageskuende blik. Kun fortælleren har med sin forhåndsviden om slutningen mulighed for at underbygge, forberede, forklare de begivenheder, hans personer står midt $\mathrm{i}$, kun han kan være »vel oppe før dag«, mens hans personer altid bliver taget på sengekanten. Således er det kun remserne som form, der lugter af mundtlig oprindelighed; deres indhold er af moderne skrifttematisk art.

Fortællerens tilbageskuende blik sætter ham til en vis grad uden for tiden: Hvad der er fortid, nutid og fremtid for hans personer, er altsammen fortid for ham. I dette er han at ligne ved den måne, han selv lader optræde som evighedens repræsentant, og for hvilken menneskelivets forviklinger tager sig sølle og latterlige ud (»Balladen om Bøledrengen $\ll$, pp.80-81). Forlenet med »dødens autoritet « kan fortælleren sætte sig ud over timeligheden og antage månens distancerende blik, som timeligt jordevæsen er han udstyret med et med-lidende menneskeblik. Det er disse to blikkes sameksistens, der kan skabe det tragikomiske perspektiv, det møde mellem farce og oph øjet alvor, fortælleren selv påpeger: »Vi er her ved et punkt hvor det farceagtige latterlige mødes og brydes med det dødsens alvorlige og avler en vis tragisk betonet humor - den som på et højere plan både Det gamle Testamente såvel som De homeriske Digte og Dantes Guddommelige Komedie afgiver så uforglemmelige eksempler på.« (»Syndefaldet «, p.64) Det, som er latterligt småt for måneblikket, kan være tragisk stort for det menneskelige. ${ }^{5}$

To dobbeltheder kunne således se ud til at være nøglen til beskrivelse af Laterna Magicas fortæller: Dobbeltheden landsbyfortæller/modernist og dobbeltheden måne/menneske.

Det er hidtil vist, hvordan fortælleren tematiserer sin egen virksomhed direkte $\mathrm{i}$ filosoferende digressioner. Denne selvtematisering optræder imidlertid også på mere indirekte vis, der hvor digtervirksomheden bliver tema for fiktionen, som det sker $\mathrm{i}$ »De stumme gæster «. Her berettes det, hvorledes de færøske digterbrødre Djuurhus som børn får besøg af tre overnaturlige spindersker. Skildringen af denne skæbnevision kan læses som en skildring af digtningens vilkår. Det bliver da novellens påstand, at digteren er den, der har erfaret skæbnen, hvilket indebærer en erfaring 
af døden. En »skæbne« er den måde, et menneskeliv bevæger sig mod døden på, ja ofte identificeres ordet med den måde, et menneske dør på: »At møde sin skæbne «, »skæbnetime« osv. Det er i kraft af skæbne- eller dødserfaringen, at digteren kan indstille sit blik som månens: I denne erfaring har han erkendt menneskelivets flygtighed.

Døden er et menneskelivs definitivitet og dermed dets definition: At definere betyder simpelt hen at afgrænse. Derfor forlener fortællerens viden om sine personers død ham med en suverænitet: Qua handlende, levende subjekter vil de aldrig selv kunne kende deres skæbne. Når fortælleren således overlegent kan sige: »Jo, det ved vi alt om« (»De stumme gæster«, p.11), bunder hans overlegenhed $i$ hans viden om slutningen, hans retrospektivitet.

Men skal vi tage Djuurhusbrødrenes skæbnevision på ordet, skal digteren altså erfare sin egen død eller opleve døden ganske tæt, før han kan give sig til at kvæde om andres død. (I фvrigt repræsenterer de to Djuurhus-brødre de to arketypiske fortællere, Benjamin definerer: "Der von weither kommende«, ham, der synger om det fjerne, og »der im Lande gebliebene «, ham, der synger om det nære. Heinesen hører naturligvis til sidste kategori.) Her kan det blive relevant at bevæge sig ud på det biografiske overdrev; Heinesen oplevede som ung sin brors død. $\mathrm{Nu}$ vi er ude i tekstens pragmatiske dimensioner, er det selvfølgelig heller ikke uden betydning for dødens fremtrædende rolle i novellesamlingen, at Heinesen er ligeså gammel som århundredet selv. Man hører den 85åriges stemme i prologens tusmørke: »Vi har det ligesom de aftenkåde børn, som nødigt vil hjem og i seng så længe der endnu er lys i luften og den skønne dag endnu ikke er helt forbi« (p.9). Det skal dog hertil siges, at allerede da både Heinesen og århundredet endnu er ganske unge, og inden broderens $d ø d$, indtager dødstanken en fremtrædende plads $i$ digterens univers, ofte knyttet til de mindre tidscykler: Dagen, der lider mod nat ("Stumt og tungt stævner vi mod mørket «), sommeren, der bliver til vinter (»Senhøstens dystre klage «) ${ }^{6}$

Såvidt fortællerens (og forfatterens) forhold til døden, der altså dels tematiseres på digressorisk filosoferende vis, og dels på det fiktive plan $\mathbf{i}$ samlingens første novelle. Nu skal de andres, dvs. fortællerens personers, død - eller deres forhold til døden - behandles. 


\section{Døden som tema og narrativ motor}

Med Mester Jakob befinder vi os tildels stadig på et fortællerens selvtematiserende plan, for hvad er denne gamle filurs store passion? - at samle uddøende ord. Her knyttes døden til digtervirksomheden på endnu et niveau, nemlig som den ordenes $d ø d$, kun ordsamleren (den skrivende digter, fortæller) kan forhindre. Hermed bliver han en livets repræsentant, en dødsbekæmper. Men døden er alligevel til stede og giver sig tilkende, når den vågne bevidsthed slukkes: Efter en dag med hengiven sig til så livsnære guder som Amor og Bacchus udsættes mesteren for et »maliciøst, men dog bramfrit kammeratligt« mareridt med døden som tema. Og se - bag dødens klamme tæppe slår en kosmisk symfoni af fuglekvidder ham i møde! Dødsangsten bliver til dødsforsoning. Den skrækfølelse, dødsvisionen fremkaldte hos de små Djuurhusbrødre, er blevet til forsoning hos den gamle kunstner.

Som kontrast hertil står den stive Stine (i novellen af samme navn), der tilbringer det meste af sit liv med at vente på en død mand. Hun ignorerer ganske enkelt døden, men dermed også livet: Den absurde fortidsrettede venten fører til det konserverede menneske, den levende døde. Når veninden og drømmersken Karen Klamp, så længe der endnu er håb for Stines forsvundne kæreste, forestiller sig hans tilbagekomst, retter hun sig mod et fremtidigt mål for den lange venten. Stine, derimod, graver tilbage i tiden og genkalder sig sit første møde med kæresten hendes »drømmesyn eller hvad man nu vil kalde det« er et stykke henrunden fortid. Derfor kan hun blive ved med at »vente«, da hun har fået besked om kærestens død. Intet under, at fortælleren tøver med at kalde Stines syn en drøm, for der er tale om en drømmeforvrængelse, en bagudrettethed, der strider mod livets dynamik: Det fremadrettede begær. Det begær, der slider på menneskene, så de ældes og dør. Stines venten på fortiden afslører en total mangel på accept af døden, både de andres og hendes egen. Hun forkaster talismanen med den dobbelte funktion: Begær-tilfredsstillelse og hudindskrumpning (jvf. Peter Brooks' analyse af Balzacs »La peau de chagrin «) og opnår derved at balsamere sig selv i levende live. Stiv som et lig er hun, den Stine!

Samlingens tre første noveller viser os således forskellige måder at forholde sig til døden på, men vi oplever her døden på en vis distance: Som vision eller som den fjerne mands bortgang. Således forberedes læseren langsomt, inden han kastes ud i de store eper, hvor han skal opleve døden på nært hold.

Men også undervejs i det episke virvar tilbydes læseren som nævnt 
små digressoriske pusterum: I »Miraklet « berettes der om tæppemester Tønnesen, der på sine gamle dage bliver så tynd og fnuglet, at han må holdes hjemme i stormvejr. En dag ser den lille gamle mand alligevel sit snit til at åbne et vindue og fare til himmels - og hermed åbenbare os døden som en lethed. En idé, der stemmer overens med prologens fremstilling af jordelivet som en tyngde: "Jorden, den formørkede soldrabant, hvor menneskene bor, prisgivet dens tyngdes fangenskab..." (p.9). 1 det lyriske titelstykke forekommer døden ikke en gang, ja dens totale modsætning er temaet: Livet i så koncentreret form, at det er lykke: »Friske lunger, myriader af ufordærvede hjerneceller - lykke, lykke, lykke! Og kom så ikke og sig at livet er lutter sorg og skam.«

Omkring disse åndehuller ligger så de fire eper, der pånær »Sprøjteprøven « alle fortæller sig frem til en død. Og døden loves fra starten, eller i hvert fald længe inden den nås i det episk kronologiske forløb (eller på russisk formalistisk: Den plads, den tildeles $i$ »sjuzet« er rykket frem $i$ forhold til den, den indtager $i$ »fabula «): »...denne dystre saga, der endte med døden i saltet...« (»Lykkestenen«, p.36), »Når Stærke-Johan endnu af mange mindes ...« (»Syndefaldet «, p.51), »Det hændte sig også, at en fange (...) gav sig døden i vold. Således gik det også Oluf, Bøledrengen« (»Balladen om Bøledrengen «, p.82) etc.

Eksemplerne er utallige på det, Benjamin ville kalde løftet om medoplevelse af døden (Benjamin XV), Sartre tegn på fortællingens nekrolog-karakter (jvf. Brooks, p.22), og Peter Brooks "the anticipation of retrospection « (Brooks, p.23). Historiens fuldstændighed - den »completition of the codes«, der er målet for »la passion du sens«(Roland Barthes) - forsikres, hvorved det læsende begær rejses.

I eperne (eller de tre af dem) optræder døden altså som narratologisk element, der sikrer fortællingens fuldbyrdelse. Men alle eperne fortæller om en død, der er fremskyndet: De to stridsbrødre i »Lykkestenen «, Konrad og Lyder, dræber hinanden, Bøledrengen dræber sig selv, og Johan $\mathrm{i}$ »Syndefaldet《 omkommer som følge af sin redningsdåd. Døden indtræder som følge af personernes aktivitet, og der kan derfor være grund til at se på dens årsager: Hvilke processer fører til den, hvad er det for nogen livstruende kræfter, der er på spil? Dødstemaet bliver således et destruktionstema.

Den destruktive kraft, der er på spil i »Lykkestenen« er noget så homerisk eller saganært som agonen, eller tvekampen - et tema, vi skal møde igen senere i bogen, stærkest fremtrædende $\mathrm{i} »$ Sprøjteprøven.« Temaet er for så vidt allerede introduceret som noget naturnært og oprindeligt i striden mellem Mester Jakobs kat og hunden Slendrian: 
"Hunden står på bagbenene, med de sorte forpoter op ad den hvide sten, mens Risna rejser børster og gør sig til en frygtelig sabelkat og udstøder truende og uhyggehvislende urskovslyde. Men sådan var nu engang livet i naturen før mennesket greb arrangerende ind.« (»Mester Jakob og Jomfru Urd«, p.17) Nu skal vi altså opleve denne oprindelige form for sameksistens bryde frem $i$ et moderne menneske-miljø.

"Lykkestenen« er historien om, hvordan den patriarkalske skibs- og jordejer Konrad P. Olsen og den moderne spekulant Lyder kommer op at strides om en stor meteorsten, der ligger i deres fælles stengærde, og som tilskrives magiske egenskaber. Striden ender, som det mange gange forudskikkes, med »døden i saltet«: Konrad og Lyder findes »gensidigt kvalte i Konrads saltkælder. En socialhistorisk funderet tolkning ville sikkert være parat til at udlægge striden mellem Konrad og Lyder hen i retning af en strid mellem feudalisme og kapitalisme. En sådan udlægning ville ikke være ukorrekt, men heller ikke særlig tankebefordrende. Allegorisk tolkning er lukkende tolkning, som reducerer analysen til ren konstatering. Det er her, at den tekstanalytiske bevidsthed kan mødes med den benjaminske fortæller. Analysen har et vist ansvar for at "væve teksten ind i det levede liv«, i stedet for at dræbe den med allegorisme som vel at mærke ikke må forveksles med strukturalisme. Den sten, der har lagt navn til »Lykkestenen «, advarer netop mod en sådan éntydig betydningsfastlæggelse i sin egenskab af mangetydig meteor fremfor stivnet metafor. Lad os $\mathrm{i}$ en ægte strukturalistisk ånd snarere betragte modsæetningen mellem feudalherren og handelskapitalisten som et påskud til at fremstille den bagvedliggende primære agonistiske drift - den, der får Lyder og Konrad såvel som USSR og USA til at betragte hinanden som fjender. Forbindelsen mellem småstadsstrid og verdenspolitik etableres ved stenens betydningsglidning fra objekt (ganske vist pseudo-objekt) for de to færingers kamp til objekt for internationale atomfysikeres interesse.

Den tvekampens død, menneskenes gensidige destruktion, der kvædes om $\mathrm{i}$ »Lykkestenen«, omgærdes af en vis mystik: De to kamphaner ser ud til at have sluttet fred med hinanden, da den indtræffer, og alene dens ofte gentagne benævnelse »døden i saltet « emmer af formular, besværgelse, myte. Men det tilsyneladende irrationelle $\mathrm{i}$ det uventede gensidige drab fremhæver blot det agonistiske princips dominans: Kindkys og offentlig fredsslutning (var der nogen, der sagde Gorbatjov og Reagan?) kan dække over det, men ikke sætte det ud af funktion. Hvad angår »døden i saltet «, tror jeg, vi skal lytte til og smage på den snarere end pinde den ud i paradigmer, altså annamme tilhørerens sanser (glem ikke, at tilhøreren i en mundtlig kultur har både ører og mund - han lytter 
ikke mindst for at kunne fortælle videre!) fremfor læserens briller. Her møder strukturalismen sin begrænsning, her bliver den systematiske abstraktion en forbrydelse mod formen. Navnet lyder vidunderligt med sin klang af mytisk enkelhed, og det er netop denne klang, der er dets budskab: Ved at forlene novellen med mytisk ekko understreger fortælleren den arketypiske status, han tillægger den. Arketypisk $\mathrm{i}$ betydningen: Konstant for den menneskelige psyke og sameksistens eller med fortællerens egne ord: Gældende »overalt, hvor mennesker bor sammen og lever af hverandre - ja måske helt ned til urbavianerne, kunne vi tilføje ved at hente et citat andetsteds (p.35). Her skal også bides mærke $\mathrm{i} » l$ lever af hverandre« og den kamp om levebrødet, der nævnes $\mathrm{i}$ novellens indledning: Det materielle begær danner her baggrunden for den agonistiske drift (det er nok intet tilfælde, at novellens vignet forestiller tre små forslugne fisk, som sågar kunne se ud til at være lige ved at bide hinanden i halen!).

Men tvekampen løsriver sig fra sin grobund og står tilbage som absurd og mægtig drift, hvilket illustreres af det irrationelle i stridens forløb, manglen på kausalitet mellem de konkrete begivenheder og stridsmandenes reaktioner. Da Konrads kone Griseldis bortfører lykkestenen, virker det ikke som forventet pirrende på striden, idet den forlængst har løsrevet sig fra sin oprindelige genstand. Derimod retter Lyder sin arrigskab mod Konrad, da han får sin fiskelast ødelagt af svamp - den agonistiske drift træder her frem med kompensatorisk funktion.

Agonen er den hurtigste genvej til døden. Konrad og Lyders begær er blevet forvrænget og forskudt til destruktionsdrift.

Det samme gør sig til en vis grad gældende for Hr. Hafner $i$ »Balladen om Bøledrengen« - tømmerkongen, der har en forskrækkelig mængde uægte børn rundt omkring i Torshavn. Her er dog ikke tale om forvrængning eller forskydning, men snarere om overdrivelse af et begær, der oprindeligt er en livsforudsæetning. I dette triste kvad bliver det imidlertid forudsætningen for Bøle-drengens tragiske død; et skaberprincip er slået om og blevet til et magtprincip, hvilket i sidste ende fører til destruktion. Den mandlige potens er paradoksal: På én gang livgivende og livstruende. Hr. Hafner vil på hybristisk vis genskabe en hel verden i sit eget billed, fylde den med små metaforer for sin egen eksistens, men derved nås den »oversameness «, som er fatal for livets (og den narrative) dynamik. (Jvf. Brooks, p.109: "Narrative is in a state of temptation to oversameness... Incest is only the exemplary version of a temptation of short-circuit from which the protagonist and the text must be led away, into detour, into the cure that prolongs narrative.«) Verden stivner $i$ et hafnersk paradigme, 
som er ensbetydende med døden.

Ingen person kan træde ud af Bøledrengens tragedie med et fortrøstningsfuldt fremtidsskuende blik, sådan som Griseldis træder ud af døden $\mathrm{i}$ saltet og herved bliver livets repræsentant (»...og hun smilede mildt og fortrøstningsfuldt ud mod horisonten, som om hun havde noget at glæde sig til«, p.50). Derfor må fortælleren selv træde til med sit livsnære lys og den kropnære gendigtning af Descartes, det afstedkommer: . Jeg nyser, altså er jeg til«. Kun som den levende fortællers stemme kan livet komme til udtryk i dette kvad, hvor døden er gået $\mathrm{i}$ hårdknude.

I det mellemliggende epos »Syndefaldet«, er livet derimod forsvarligt repræsenteret i Varme-Fanny, og parallelt med de andre noveller er det hende, der får lov at træde frem i profil, da de, der skal dø, er døde.

Heinesen demonstrerer kompositorisk sin bibelkundskab ved at afslutte historien om Konrad og Lyder med præstens citat af Lamechs (eller Lemeks) sang, som dermed kommer til at stå lige før »Syndefaldet«, ligesom den i Biblen står lige før syndflodsberetningen. Jeg tillader mig her, med fare for at blive beskyldt for strukturalistisk reduktion, at abstrahere syndefald og syndflod sammen i den falles idé om det menneskelige hovmod, der straffes. På sin vis er ikke alene "Syndefaldet «, men også de to efterfølgende eper syndefalds/syndflodsberetninger: »Balladen om Bøledrengen« $i$ kraft af den hafnerske hybris og »Sprøjteprøven « som "syndflodspantomime«. ("...denne hemmelige udladning $\mathrm{i}$ natur og menneskesind, denne syndflodspantomime, kunne man også kalde det, ja, hvorfor ikke? « hedder det $\mathrm{i}$ indledningen til »Sprøjtepr $\varnothing-$ ven «.)

Lemek er en af mosebøgernes gode gamle slagsbrødre, kendt for at have pralet således overfor sine hustruer: »Blev Kain hævnet syvfold, saa hævnes Lemek syv og halvfjerdsindstyve Gange! «(1.Mos.4.24) Opfattelsen af ham, som sikkert mange andre af de første mosebøgers saftige helte, er undergået en betydningsglidning i Det gamle Testamentes tilblivelseshistorie: Oprindelig er hans vilje til blodhævn, hans agonistiske drift, blevet betragtet som beundringsværdig - og faktisk gengives hans hovmodige sang i Biblen uden direkte kommentar. Til gengæld har man altså placeret den kort før syndflodsberetningen, således at den - i kraft af en narrativ logik! - passer ind i en overordnet gammeltestamentelig norm om det menneskelige hovmod, der står for fald.

En sådan betydningsglidning vidner om de jødisk/kristne begrebers uoprindelighed, og Heinesens alternative syndefaldsberetning kan siges at tematisere denne uoprindelighed. Når allerede den gammeltestamentelige etik er på vej bort fra oprindeligheden, hvordan står det da ikke til med 
den nytestamentelige? I »Syndefaldet « kommer de kristne begreber om "godhed « og "synd " ganske til kort overfor den almægtige Eros. Vi hører her, hvorledes Stærke-Johan ikke kan modstå varmen fra Varme-Fanny, som desværre er gift med hans bedste ven Fingal. I troen på, at han som en god kristen må bekende sin synd, fortæller han Fingal om den dobbelte utroskab, hvorpå denne forsøger at drukne sig. Igen viser Johan sig som en god kristen: Han redder Fingal, som derefter spærres inde på galehus, mens Johan selv dør som følge af sin næstekærlige redningsdåd.

Men tro nu ikke, at Fanny er en modbydelig mær - hun er langt hinsides det gode og det onde, umulig at presse ind $\mathrm{i}$ en kristen tolkning. Således hedder det om det øjeblik, hvor Johan lader sit begær efter Fanny finde sin forløsning: »- det drejer sig om et af disse lynnedslag som naturkræfterne i oprindelig artsbevarende øjemed jævnligt arrangerer og som ytrer sig i betingelsesløse magtbud, der kan slå selv den bedst pansrede kalvinist af marken « (p.63). Det destruktive er altså ikke at finde i det driftsliv, Fanny reprasenterer, men i den måde, det tolkes på, i misforholdet mellem kristen terminologi og natur. Hvis Stærke-Johan nedbrydes, er det ikke fordi, han har ladet sig styre af sit erotiske begær, men fordi han ikke acepterer dette begær; det er ham, der opfatter det som synd og som sin kristne pligt at bekende denne. Og hvad kommer der så ud af hans bekendelser? Fingal viser tilsyneladende accept og tilgivelse, men ikke desto mindre skal den viden, han her forsynes med, i sidste ende føre til hans forsøg på selvdestruktion.

Trækkes linien stramt op, leder Johans gode kristne handlinger altså til døden. Døden som følge af synden viser sig at være døden som følge af kristen mistolkning, af forsøget på at presse naturen ind $i$ en alt for snæver terminologi.

Men det er måske ikke alene den kristne terminologi, der er for snæver: Når Fanny kan volde mændene så mange kvaler, er det også, fordi de tolker hende i en individuelt-subjektivt centreret diskurs. De dør (eller ønsker at dø), fordi de tager livet (Fanny) alt for personligt.

Det afsluttende epos "Sprøjteprøven« adskiller sig som nævnt fra de $\emptyset$ vrige ved ikke at beskrive én eller flere personers død. Til gengæld går de destruktive temaer, som i de andre noveller har ført til døden, igen: Agonen og den overdrevne mandlige potens. Her fortælles det, hvordan man i 1910 'ernes Torshavn fejrer en ny og teknisk brandsprøjtes ankomst til byen.

Den lokale Dionysos, Brandmester Umbertsen, får lov at demonstrere sprøjtens kraft for en jublende folkemængde, som han gavmildt overøser med vand, indtil ingeniør Blüthner, fremskridtets og fornuftens mand, 
forarget skrider ind . Han er dog så civiliseret, at han ikke selv udkæmper sin part i tvekampen, men lader sig reprasentere af den udøvende magt. Asse Betjent besejrer slutteligt Umbertesen, men da er sprøjten forlængst holdt op med at virke, og den festende folkemængde forlængst begyndt at interessere sig for helt andre ting.

Som i »Lykkestenen « forbindes småstadens strid med supermagternes på ganske eksplicit vis: »Sprøjten selv tog afgørelsen i sin hånd. Det er ikke mindst på dette punkt ligheden mellem denne sprøjteprøve og verdenskrigen falder i фjnene« (p.132). Den mandlige potens symboliseres overvældende $\mathrm{i}$ den store svulmende slange, som ikke alene bliver træfpunktet for det lille lokale og det store internationale samfund, men også for fortid og nutid, myte og modernitet. Både Umbertsen og Blüthner har projiceret deres mandlige stolthed ud i slangen: Umbertsen forlener den med en hedensk præsts rituelle magt, mens den magt, den skal give Blüthner, er den moderne tekniks.

Det er oplagt at betragte de to stridsparter adornistisk: Blüthner som den tekniske hjerne, der opfinder smarte naturbetvingende redskaber; Umbertsen som udtryk for den voldsomme trang til potensudfoldelse, der med dẹ nye redskaber får nye og mægtige muligheder. Teknikken kan måske betvinge den ydre natur, men ikke den indre. Tværtimod kan de indre primære drifter forstørres til det massedestruktive ved at tage den ydre betvungne natur i brug. Den rationelle tanke bliver irrationalismens redskab. Denne bevægelse viser sig i novellen også derved, at redskabet løsriver sig fra det formål, det oprindelig er skabt til: Det bål, der er opstillet til demonstration af sprøjtens effektivitet, bliver aldrig slukket.

I en sådan abstrakt udblødning kan man altså betragte Umbertsen og Blüthner som samvirkende faktorer $\mathrm{i}$ den moderne rationalismes irrationelle destruktivitet, som har frembragt to verdenskrige. Men Adorno-modellen er ikke vandtæt: Umbertsen bruger nemlig ikke kun sin sprøjte i destruktivt øjemed: Hans vandoverrisling af publikum fremkalder også en erotisk stemning, altså en forudsætning for skabelse. Vi kommer dermed tilbage til potensens paradoks, som vi før har mødt det hos Hafner; Umbertsen forbindes med ødelæggende såvel som skabende kraft og bliver en hel lille jordånd. Og det bliver endnu en gang det skabende element, der får det sidste ord: $\mathrm{Da}$ striden er udkæmpet og glemt, begynder et muntert og frugtbart natteliv.

De destruktive kræfter, vi møder i Heinesens episke verden, kan opsummeres i stikord som materialistisk begær (Konrad og Lyder), overdreven trang til selvekspansion (Hafner), teknologisering af en primær aggression (Blüthner og Umbertsen) og endelig problemfor- 
skydning (Lyders raseri mod Konrad, da hans fisk går tabt) og mistolkning (Johan og Fingals mangelfulde begrebsapparat, trangen til at tillægge noget så indifferent som en sten betydning).

Der findes altså én kreds af destruktionstemaer omkring mandlig potens og begær, og en anden omkring tolkningsvanskeligheder. Agonen bliver de to kredses bindeled: Den er udtryk for den fejltolkede mandlige potens, det forskudte begær, hvis skaberkraft er vendt til destruktion. Tolkningstematikken bliver naturligvis særlig interessant for den, der prøver at tolke novellerne - herom mere afslutningsvis.

\section{Forventningens absurde barnelykke}

I forsøget på at indkredse de destruktive kræfter i Laterna Magica har vi allerede strejfet, hvad der burde være deres modsætning: De skabende kræfter, livets repræsentanter. Livet får med konsekvens sidste ord: Mester Jakobs eksistensbekræftende tømmermænd, moderens hjemkomst, der jager de små Djuurhus-brødres angst på flugt, fortællerens nys $\mathrm{i}$ »Balladen om Bøledrengen«, Griseldis' fortrøstningsfulde skuen ud mod horisonten og Fannys gamle men stadig varme skikkelse, den erotiske stemning efter sprøjtedysten.

I god overensstemmelse med Heinesens øvrige forfatterskab forbindes liv og skabelse i påfaldende grad med kvindeskikkelserne: Mødrene (BøleAnna, Fru Djuurhus), elskerinderne (Jomfru Urd og Fanny), de praktisk og konkret tænkende (Griseldis' retten sig mod det konkrete objekt, stenen, da den af mændene er ophævet i absurd abstraktion). Den næsten religiøse aura, kvinderne forlenes med $i$ andre Heinesen-værker, finder vi også her: Annas Mater Dolorosa-skæbne og Fannys elskovssuk, der klinger som en bryllupssalme. Kvindernes livsnærhed skal dog ikke forlede os til at opstille stive modsætningspar som død/liv, mand/kvinde, minus/plus: De hidtil indkredsede temer - paradoksal potens og tolkningsproblematik - spæender netop ben for en sådan fastlåst tolkning, som i sin skematisering af modsætninger undsiger paradokset.

Et tema, der umiddelbart kunne se ud til at befinde sig på livsiden, viser sig således at rumme en dobbelthed. Det er temaet om forventning eller venten. Allerede Mester Jakob oplever »Den absurde forventnings barnelykke «, mens han venter på sin Jomfru Urd - således udtrykkes her, hvad der senere skal tematiseres i titelnovellen. I det lille lyriske "Laterna Magica «-stykke bindes liv og forventning sammen og bringer os langt væk fra døden til ungt koncentreret og ufordærvet liv. Det "absurde" ved 
forventningen hos de små tøndebåndstrillende drenge er, at den er ligeglad med sit objekt - lykken findes ikke i det forjættede objekt, men $i$ vejen hen mod det, ikke i det begærede, men i begæret selv. Forventningen, den berusende anelse om fremtidig forjættelse, bliver en eksistentiel størrelse, ganske uafhængig af, om forjættelsen nogensinde nås.

Umiddelbart kan forventningens absurditet ikke tilskrives de samme årsager hos Mester Jakob, for han når sin forjættelse, han får sin kirsebærvin og sin Jomfru Urd. Hvad der derimod kan virke absurd, er at denne gamle mand bliver ved med at føle »forventningens barnelykke« - barnelykke, fordi den jo er en projektion i fremtiden, som kan virke mere rimelig ved livets begyndelse end så nær ved Gråskallebryggen. Mester Jakob skal nok ikke kaste sig særlig langt frem i tiden, før han havner i færgemandens båd. Alligevel pulserer den fremtidsrettede drift stadig i ham, simpelt hen fordi den er et eksistentiale: Så længe der er liv, er der forventning. Og omvendt: Forsvinder forventningen, forsvinder livet. Det er det, der er sket for Stine, der i sin fortidsrettethed opnår mumieeksistensen, døden-i-livet. Men fremtidsrettethed er også dødsrettethed, idet menneskets ultimative fremtid er døden. Heraf forventningens absurditet, der er nært beslægtet med potensens paradoks: En og samme drift er livsgivende såvel som livstruende.

Forventningen kan også på mere direkte vis antage livstruende karakter. Dette sker, når den finder sit objekt i andres ulykke, udarter til sensationslyst og hermed bliver dødens allierede. Det er sådan, den udvikler sig i »Sprøjteprøven «; hele denne novelle lades op med den spændte forventning om »det, der skal ske« (p.121,124,130)...»som vi alle har ventet på uden rigtig at vide hvorfor « (p.119) - og det, der skal ske viser sig tildels at være de destruktive agonistiske kræfters frie spil. Den gentagne insisteren på det forventede objekts ubestemthed understreger endnu en gang forventningens karakter af selvstændig, eksistentiel kraft.

\section{Mikrokosmos}

Potensens paradoks og forventningens absurditet er som nævnt eksistentialer i novellesamlingens univers. Og dette skal forstås på helt radikal vis: Som noget, der gælder for enhver menneskelig eksistens af enhver dimension til enhver tid. De antager hermed karakter af arketypiske størrelser og Færøerne af et mikrokosmos - en idé, der må siges at være en gennemgående og meget bevidst struktur i forfatterskabet. 
Allerede $\mathrm{i}$ den introducerende aftenkåde tusmørkestemning præsenteres vi for denne mikrokosmiske tankemåde: Børnenes hyl fra »Jordemoderbakken « betegnes som »Urtidsmusik « og signalerer hermed ikke blot enkelte livs begyndelse, men hele menneskehedens, byvandringen forst $\varnothing \mathrm{r}-$ res til livet selv, Charon omplantes fra Acheron til Gråskallebryggen. Den lille færøske havneby forstørres til mytisk univers, og vi får snart at vide, at »Småstadens nøgler passer i næsten alle menneskelige dørlåse « (»De stumme gaster «).

Når der kan være tale om de åbenlyst antydede paralleller mellem den lille lokalverden og den internationale politik, er det ikke fordi novellerne er skrevet som allegorier. Følgende fortællerkommentar fra »Sprøjteprøven« kan endog læses som en direkte advarelse mod allegorisk tolkning: »De to ting...har ingenting med hinanden at gøre, men har alligevel, som vi skal se, noget tilfælles. Noget i selve mønstret (p.118). Det er næsten som at høre Gerard Genette fremhæve den strukturalistiske interesseforskydning fra analogien til homologien: "L'analyse structurale doit permettre de dégager la liaison qui existe entre un système de formes et un système de sens, en substituant à la recherche des analogies terme-à-terme celle des homologies globales.《 (»Structuralisme et critique littéraire«, in Figures I)

Det nytter ikke noget at ville finde et allegorisk 1-1 forhold mellem sprøjteprøve og krig, til gengæld opfordres læseren til at være opmærksom på mønstret, det psykologiske mønster, der ligger bag personernes handlinger. Bag de på tværs af tid og rum gående paralleldragninger ligger idéen om »det fælles mønster «, om særlige primære psykologiske mekanismer, som er drivkraften bag den lille færings såvel som den store toppolitikers handlinger, bag sagaheltenes såvel som nutidsmenneskenes, bag Jomfru Marias sorg såvel som Bøle-Annas. Det er idéen om »Tat twam asi« - »jeg er dig og du er mig«, der afstedkommer det færøske mikrokosmos.

Den paralleldragning, der går på tværs af den tidslige dimension, kunne måske også bunde $\mathrm{i}$ fortællerens overlegne forhold til tiden; den fornemmelse af at stå udenfor tiden, som bunder $i$ hans tilbageskuende blik. Han har magten til at gøre fortid til nutid og endvidere lege med dens kronologi, hvilket vel let kan få ham til at føle, at »fortid, nutid og fremtid er samme pulje« som den kloge Nelly $i$ »Balladen om Bøledrengen « udtrykker det (p.88).

En ganske ekstratekstuel faktor kunne også have betydning for den mikrostrukturelle tanke: Det forhold, at forfatteren lever $\mathrm{i}$ et samfund, hvor man uden problemer kan hedde Napoleon Olsen, og hvor det, der 
andetsteds ville betragtes som hørende til meget forskellige tidsaldre, ser ud til at sameksistere: En mundtlig kultur og en skriftlig kultur (fæerøsk skriftsprog tager endog sin begyndelse så sent som i det 18. århundrede!), tørvetækkede boliger side om side med parcelhuse, kædedans og disco osv. Og endvidere et samfund, hvor naturen er helt tæet på og stadig fremstår som en magtfuld kraft: Tågen kan stadig komme væltende og bringe vandrerens liv i fare, havet kan stadig opsluge menneskeliv. Dødsoplevelsen rykker nærmere, og man kan få en fornemmelse af at være tæt på urkræfternes frie spil. Naturens kraft er ligeså åbenlys for nutids- som for oldtidsfæringen, og man kan forestille sig, at den har været en ikke uvæsentlig inspirationskilde til den i Laterna Magica fremstillede eksistentielle dobbelthed i menneskets drift: Havet, som både giver og tager, har en del tilfælles med potensen, som både skaber og фdelægger.

En af de mange ting, vi kan lære af Latema Magicas vise fortæller, er, at tolkning kan være destruktiv. Meteorstenen bliver midtpunkt for tumult og ulykke, fordi personerne partout skal tillægge den betydninger. Mændene går under, fordi deres tolkninger af Fanny er så mangelfuld. Hafner vil gøre hele verden til et Hafner-paradigme, hvilket fører død og ulykke med sig. Overført til det teksttolkende niveau rummer dette naturligvis en kraftig advarsel til tekstanalytikeren om at undgå stiv eller snæver betydningsfastlæggelse. $\mathrm{Og}$ en sådan undgår vi bedst ved at være lydhøre over for teksten, at være lige så opmærksomme på dens bevægelser som den, der lyttede til Benjamins fortæller. Her mødes Peter Brooks og den urgamle tilhører.

Betragter vi de bevægelser, der fører personerne frem mod deres død fremfor blot at opfatte Lyder og Konrad som kapitalisme og feudalisme, Bøledrengen som ødipalt frustreret, Fanny som det rene id, Umbertsen og Blüthner som myte og modernitet, kvinden som den gode skaber og manden som den onde destruktør osv., kan vi nemlig komme videre end til den blotte konstatering. Vi kan lære noget af Heinesen, noget om, hvordan vi kan undgå at fremskynde døden eller selv eksistere som levende døde. Den eksplicitte levende fortæller, vi møder i Laterna Magica er ikke bare konstruktion - novellerne er i slægtskab med den urgamle erfaringsformidlende fortællekunst. Og er det end eo ipso en umulighed at genoplive denne $\mathrm{i}$ vort skriftgennemsyrede samfund, kan vi i det mindste forsøge at indoptage en simuleret tilhørerrolle $\mathrm{i}$ tolkerrollen, lytte efter »den gode historie« - kort sagt: Slå ørerne ud! 


\section{Noter}

1. Jvf. Glyn Jones, p.242: »...det opdigtede Torshavn, der går igen $i$ forfatterskabet, og som derfor efterhånden næsten bliver til virkelighed for den, der er fortrolig med forfatterskabet.«

2. Jvf. Ong, f.eks. p.146: »The oral song (or other narrative) is the result of an interaction between the singer, the present audience and the singer's memories of the songs sung."

3. Benjamin påpeger, at historiefortælleren (der Chronist) i modsætning til historieskriveren (der Historiker) ikke skal formidle begivenhedernes indbyrdes årsagssammenhæng, men deres "Einbettung in den grossen unerforschlichen Weltlauf«, altså henføre dem til en skæbneinstans.

4. Et andet eksempel på denne bevidsthed om mytificering er beskrivelsen af Tønnesen og søn: »...en slags hellige og evige mænd, skønt vi jo ellers nok vidste, at de kun var almindelige dødelige mennesker.« (p.75)

5. Måne- og menneskeblikket kan eksemplificeres ved at følgende to fortællerkommentarer sættes overfor hinanden: „Ak, alt dette er naturligvis småtterier, som det $\mathrm{i}$ grunden er uværdigt at dvæle ved...« siger månefortælleren (p.36), hvorimod menneskefortælleren har en anden holdning: „Lad os nu glæde os over hverdagens komedier og baduljer...« (p.18)

6. Citaterne stammer fra henholdsvis "Sol og blæst« og »Senhøst «, begge digte fra Arktiske elegier, 1921.

\section{Bibliografi}

Walter Benjamin: „Der Erzähler«, in Gesammelte Schriften II.2, Suhrkamp Verlag 1977. (Der henvises til de med romertal markerede afsnit)

Peter Brooks: Reading for the Plot, Vintage Books, New York 1985.

Gerard Genette: Figures I, Seuil, Paris 1966.

W. Glyn Jones: Farø og kosmos, Gyldendal 1974.

William Heinesen: Latema Magica, Vindrose 1985.

Walter J. Ong: Orality and Literacy, Methuen, New York 1982. 